\title{
The Curriculum and Community Enterprise for Restoration Science: Engaging Marginalized Students in STEM Fields through Data Acquisition and Computational Thinking
}

\author{
Lauren Birney ${ }^{1, *} \&$ Denise McNamara ${ }^{1}$ \\ ${ }^{1}$ STEM Education, Pace University, New York 10038, USA \\ *Correspondence: STEM Education, Pace University, New York 10038, USA. E-mail: 1birney@pace.edu
}

Received: July 9, 2021

Accepted: August 13, $2021 \quad$ Online Published: November 15, 2021

doi:10.5430/jct.v10n4p82

URL: https://doi.org/10.5430/jct.v10n4p82

\begin{abstract}
In an increasingly data driven world, the need for a qualified STEM workforce is essential. Increasing the diversity of this workforce increases the social and economic possibilities for the individual as well as national economic status and global prominence in innovation and technology. The Curriculum and Community Enterprise for Restoration Science has created a nexus between STEM education and possible college and career pathways in data science through ecological experiences in the classroom and in the field. Focusing on data collection and interpretation, New York City students from underserved communities are exposed to the local marine environment and efforts to restore aquatic species as well as the water quality in New York Harbor. The use of an innovative and motivating curriculum for both students and teachers bolstered confidence in acquired skills and content. By introducing students to these heretofore untapped STEM areas of interest, the BOP CCERS + STEM C Project has created opportunities in college and career options for underrepresented populations and the possibility of growing a more diverse STEM workforce.
\end{abstract}

Keywords: computational thinking, critical thinking, ecology, data science, diversity, college and career readiness

\section{Introduction}

In March 2020, the world as we know it was brought to a standstill. Entrenched in the worst pandemic in over a century, COVID-19 wrought havoc. Most of our incoming information about COVID-19 became speculation mixed with a vast accumulation of data. A myriad of percentages, graphs, and tables unfolded the story of the pandemic and its grip on the human population of the earth. We were bombarded for 16 months and arguably forevermore, with data that told the story. As the data-driven evolution of the virus became the go-to for the public, it also guided the scientific community. The symptoms of the virus, the characteristics of those most vulnerable to COVID-19, and the results of the clinical trials all helped to flesh out the makeup of the virus and how to begin to reverse its grip.

The medical discoveries that finally lead to more aggressive health care and the development of lifesaving vaccines relied heavily on the trial-based results and the data they provided.

Needless to say, data collection, analysis, and interpretation played a most vital role in harnessing the virus and reversing the sickness and death cycle. Arguably, taking control of the pandemic relied heavily on the global communication of databases and pertinent information about the virus, coupled with the medical expertise that lead to the life-saving vaccines. Preventing the deaths of thousands of people is the result of education, career choices in STEM and the collection of pertinent data.

Data science is described as a scholarly phenomenon that rests on the interplay of technology, analysis, and interpretation (Boyd \& Crawford, 2021). With the advancement of technology and the vast amount of digital data that is continually being produced, data science has become one of the more rapidly growing occupations within the last century. Combining scientist, mathematician, computer scientist, and analytics analyst, the task of unraveling large quantities of data is a major challenge in solving quandaries in healthcare, finance, and academic research to name a few. Arguably, the most vital collection and interpretation of data are that which will aid in resolving the sustainable development goals set forth by the United Nations General Assembly in 2015. These seventeen 
interconnected goals are designed to be a "blueprint to achieve a better and more sustainable future for all" (United Nations, 2015). Two years after these goals were set forth, a United Nations resolution was adopted to identify specific targets for each of these goals and to monitor these targets through data collection and interpretation. To achieve this, an online tracker, SDG-Tracker was launched, https://sdg-tracker.org (Ritchie \& Roser, 2018).

Data science can provide a variety of skills to students. Exposure to data science early in their education extends their understanding of data science to a deeper level than just technical computer knowledge. By having the ability to explore trends in data, students can develop hypotheses and explore compelling societal issues for causation and correlation. Students who choose high school and post-secondary coursework that involves data learn how to collect, analyze and report on their findings and interpretations. Being able to synthesize data and communicate findings into information that is palpable for a general audience is one of the key $21^{\text {st }}$ Century skills needed for success. This success leads to a plethora of STEM career opportunities. Multidisciplinary project teams can be found in all areas of the workforce and pair data experts with product engineers and managers. These multidisciplinary teams then communicate their findings to the larger corporate entity and the public. The key is early exposure to data science content and skills.

Seizing this opportunity to bolster educational opportunities and career readiness content and skills in STEM, academia developed the Next Generation Science Standards (2013), creating a conduit for all students to be given a set of performance expectations that would lead them to a deeper understanding of science, technology, engineering, and mathematic (STEM). Developed by a consortium of educational leaders in several states, the NGSS includes classroom practices such as planning and carrying out investigations, using mathematical and computational thinking, and analyzing and interpreting data (National Research Council, 2012). Intending to create an informed citizenry and promoting equity and diversity, the NGSS performance expectations reflect high academic goals for all students. Inclusiveness is fundamental in terms of social justice, especially for those marginalized populations who have been underserved by the education system and therefore have had limited opportunities for economic and social advancement. One of the eight key scientific and engineering practices in the Next Generation Science Standards is computational thinking (NGSS, 2013). The Next Generation Science Standards are intended to raise the scientific literacy of all students and in so doing, pique their interest in science so that more choose a college major and/or career in the STEM fields (Science, Technology, Engineering, and Mathematics).

Although much has been written and discussed about the lack of diversity in STEM (Science, Technology, Engineering, and Mathematics), little movement has been made to ameliorate the situation. As stated in a recent UNESCO 2019 Women in Science Report, only $29 \%$ of workers in research and development are female. When we consider scientific research as group problem-solving, instead of the unveiling of individual brilliance, diversity becomes paramount to excellence (Gibbs, 2014). Gender diversity is most evident in academia and technology, although there is a lack of overall diversity as well. Recent studies show that the number of female students enrolled in science, technology, engineering, and mathematics (STEM) related disciplines have been decreasing, while the number of women resigning from technological job positions remains unacceptably high (Botella, Rueda, Lopez-Inesta \& Marzal, 2019). After examining college graduates from 4-year institutions (1996-20216), the National Science Foundation found inconsistencies in diversity efforts. Over almost two decades, Latino graduates have grown from 5.9 to $10.4 \%$ of graduates in this field. However, the proportion of Black students has decreased over this period from 4.7 to $3.86 \%$ (Hamrick, 2019). In the United States, only $57 \%$ of black students have access to a full range of math and science courses necessary for college readiness, compared to $81 \%$ of Asian American students and $71 \%$ of white students (U.S. Department of Education for Civil Rights, 2014).

Long-term economic growth and global competitiveness are dependent on increasing a diverse workforce. Changing demographics in the United States suggest that enhanced diversity raises the potential for economic growth by capitalizing on the expanded pool of talent and perspective. More STEM workers are needed to maintain not only the nation's economic prominence but also its status as the global leader of technological and scientific innovation (National Academy of Science, 2010). Statistics show that the majority of children born in the United States are classified as children of color and over half of all the children born are female. By perpetuating the exclusion of marginalized populations, we not only limit the various perspectives that are available to us but we also limit our ability to be competitive in the global advancement in STEM and ignore a great economic opportunity for all students. Increasing the representation of women and people of color in STEM fields can help increase diversity, creativity, and STEM innovation (Kricorian, Seu, Lopez, Ureta \& Equils, 2020).

In 2020, the COVID-19 pandemic claimed the jobs of millions of people. COVID-19 changed the face of the employment sector, with future employment becoming more focused on technology and intelligence. As stated on the 
Sure Jobs: Education, Career and Money website (https://surejob.in/most-interesting-jobs.html), April 20, 2021, the 10 most interesting jobs in 2021 are concentrated in the area of technology with several focusing on the field of data science (Nagrale, 2021). Digital marketer, data analyst, and data scientist hold the top three positions on the list. The proliferation of data, its collection, interpretation, and communication triggered the emergence of the field of data science.

A conglomerate of skill sets and multiple content areas comprise data science. Computer science, statistics, and mathematics work in tandem with topics in science, marketing, finance, and ecology to name a few. Employment involving data science has mushroomed and with this expansion, there is an increase in the number of data science courses and programs at the graduate and undergraduate levels. Nevertheless, data science is still in its infancy, and steps should be taken to expand data science beyond the college entry-level. There is a need to expose younger students to data science. High school students, especially those from underrepresented populations cannot choose a major for which they know nothing. College and career readiness in data science and STEM, in general, need to be included in secondary academic programs. Future data science programs will need to incorporate a variety of skills, using a range of tools including statistical analysis, visualization, and tabulation to analyze data and derive meaning. Large and complex data sets require strong analytic skills. Oral and written communication skills are also necessary to engage with diverse audiences about real-world problems, to work in teams, and to participate in effective problem solving for both technical and ethical dilemmas encountered in uses of data science (National Academy of Science, Engineering, and Medicine, 2018).

\section{Method}

Currently, in its $7^{\text {th }}$ year, the original Curriculum and Community Enterprise for New York Harbor Restoration in New York City Public Schools (National Science Foundation DRL \#1440869) $(\$ 5,374,972.00)$ model was designed to augment the pre-existing Billion Oyster Project that was being conducted at the Harbor School. Located on Governor's Island in upper New York Harbor, the project was originally intended to reseed NYC Harbor with a billion oysters by 2025. The Billion Oyster Project, from hence on known as BOP, was a smaller harbor restoration plan that relied on citizen scientists and students from the Harbor School to achieve its mission. The National Science Foundation-funded Curriculum and Community Enterprise for Restoration Science, heretofore known as BOP CCERS, was a major expansion of the project. By adding five pillars on which the project would operate, the level of community participation mushroomed to include several industries and educational partners, leveraging strong community partnerships to provide real-world learning to students in middle and high school. The STEM BOP CCERS Project became one of the most expansive efforts focused on place-based environmental education to be conducted in the school in New York City (Birney \& McNamara, 2017).

By including the nation's largest and most diverse school district (1.1 million students) it also became an extraordinary opportunity for increasing access to high-quality STEM education in underperforming schools and engaging historically underrepresented communities in the STEM Career areas.

Adding the New York City Department of Education to the project became a major game-changer. Curriculum development began for the teachers as well as the students involved in the project. With the guidance of science education faculty from Pace University, researchers from the National Academy of Science, and field experts from the Lamont-Dougherty Observation center, among others, teachers and students were immersed in the discovery of restoration science as it pertained to their local environment. Research indicates that students who are engaged in real-world, hands-on science are more successful in science and have a deeper understand and appreciation of the content (Foley \& McPhee, 2008). They are motivated and involved to a greater extent when actively engaged and intellectually interested. Schools also benefit from the increased resources, supports, and relationships resulting from the development of trusting school-community partnerships (Gross, et al., 2015)

Through constant monitoring, testing, and evaluation, the STEM BOP CCERS Project underwent several iterations. Although the successes overwhelmingly outweighed the challenges, a need for student motivation and pursuit of the study of STEM curricula and possible STEM-related career choices was evident. To meet this need, the Curriculum and Community Enterprise for Restoration of a Keystone Species in New York Harbor (National Science Foundation DRL \#1759006) grant was awarded in March 2018. Slated to promote practices that increase student motivations and capacities to pursue careers in fields of science, technology, engineering, or mathematics (STEM), the project expands and tests the locally relevant, problem-based learning begun in the original STEM BOP CCERS project. In September of the same year, the Integrating Computational Science with Environmental Sciences Associated with Habitat Restoration and Education in New York Harbor (National Science Foundation DRL\# 1839656) expanded the 
project even further. It supplemented the increasingly robust project by integrating computational thinking, data literacy, and statistical concepts with the field-based STEM curriculum model for middle school students that focuses on science fields associated with habitat monitoring and restoration.

STEM Curriculum + Community Enterprise for Restoration Science

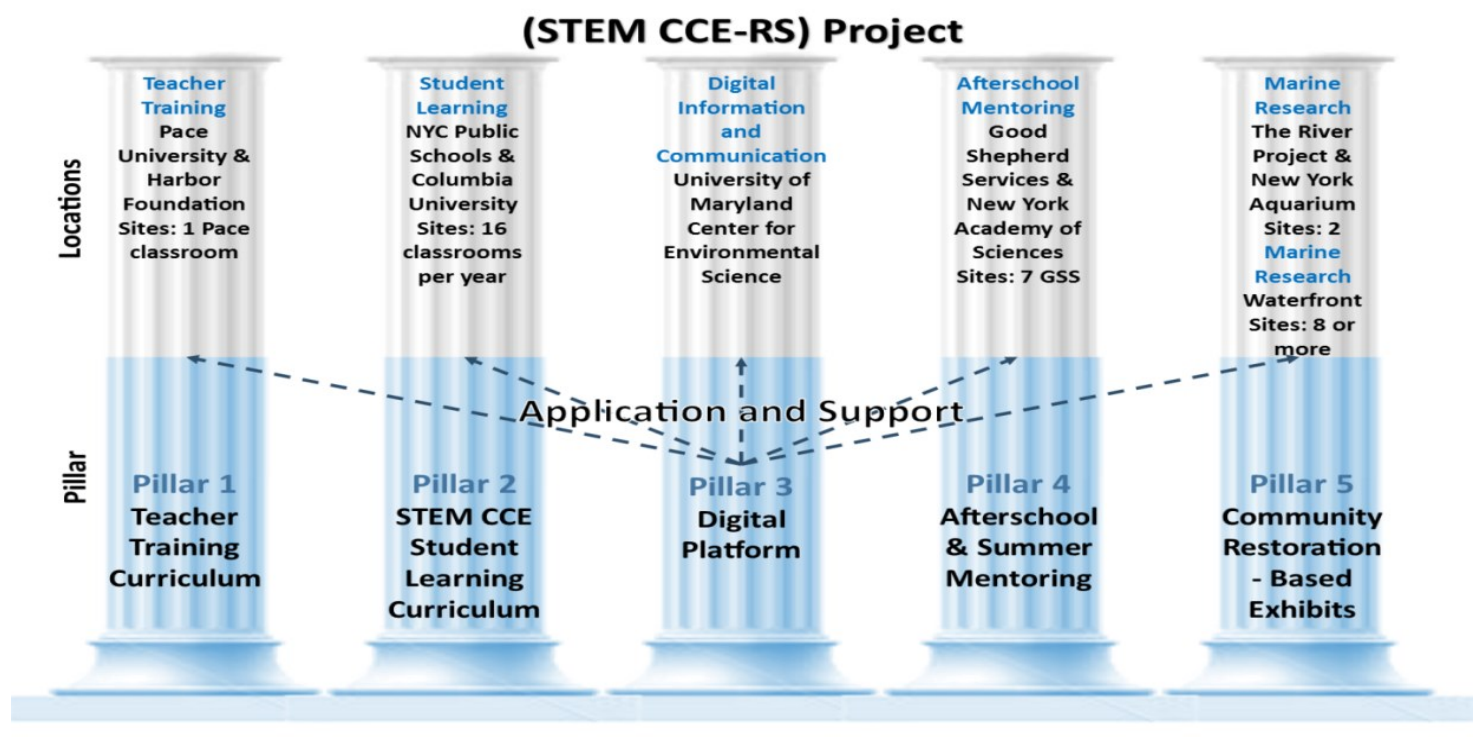

Figure 1. The Original Five Pillars of the STEM CCERS Project

Widely known as Phase III of the BOP CCERS STEM + C project, the additional pieces build on the existing success of the original project by augmenting the original five pillars of the framework. This is being done by heightening student interest and understanding of restoration science and possible post-secondary education and career pathways. Additionally, the creation of curriculum units that address computer and data science are being implemented to broaden the students' knowledge base and expose them large databases associated with restoration science and specifically, databases associated with the New York Harbor. Further development on the BOP Digital Platform enables the students, teachers, researchers, and scientists to cull the most relevant data for analysis and interpretation. The project's research agenda seeks to understand how best to engage and retain students from historically underrepresented communities in pursuing the technical skills and knowledge needed to advance careers in the fields of environmental science, biology, engineering, ecology, urban planning, and design. Equity in science learning occurs when individuals from diverse backgrounds participate directly in established scientific and professional communities, connecting home and community cultures to science (National Research Council, 2009).

The new student curriculum addresses computer science topics as well as methods for the collection, storage, and analysis of scientific data, with data shared on the BOP Digital Platform serving as the starting point. This curriculum reinforces other programmatic efforts to engage students in a meaningful and personal exploration of $\mathrm{STEM}+\mathrm{C}$ career pathways. While science identity is important for all students, it is particularly important for those who are traditionally underrepresented in the physical sciences, who are least likely to identify as a "science person" (Hazari, Sadler \& Sonnert, 2013). Technical professionals from universities and industry will share technology best practices, and provide informal advice and mentoring to students and provide the opportunity to meet and learn from $S T E M+C$ professionals who are active in the field. This in turn will lead to a long-term support system for marginalized youth in which students demonstrating exemplary motivation or aptitude over the course of a school year are then nominated to join a small cohort of 10 to 20 students to be formally mentored by a STEM professional. Each cohort is matched with one dedicated mentor, either a research associate staff member of BOP or participating volunteer graduate student. Working alongside BOP research associates or other graduate students, a select number of $11 \mathrm{th} / 12^{\text {th }}$-grade students will also be assigned to mentor middle school cohorts. Mentors meet in person once per 
month with their cohorts and a curriculum is provided for a complete two-hour session. Mentors are also encouraged to lead offsite trips to aquariums and provide additional fieldwork opportunities. Unfortunately, for students underrepresented in the physical sciences, there are several factors that contribute to a lack of this sense of belonging, in particular, the lack of role models in the STEM disciplines. The BOP CCERS STEM + C project has addressed this lack of diversity through near-peer mentoring. As defined by Zaniewski and Reinholtz (2016), "near-peer mentoring is a dyadic platonic relationship between a more experienced student (mentor) and a less experienced student (mentee) at the same institution, with frequent, direct, face-to-face contact". Feeling a greater sense of belonging in STEM can have a positive impact on academic achievement and retention in STEM, particularly for women and students of color (Rattan, Savani, Chugh, \& Dweck, 2015). The relationship underrepresented students develop with their mentors may have an influence on their STEM belonging (Robnett, Nelson, Zurbriggen, Crosby, $\&$ Chemers, 2018). This may be especially useful in increasing the inclusion of underrepresented groups and thus, the diversity in STEM.

For the next generation of students to interact with increasingly bulky data sets, students must be able to hone and make use of their analytical skillset. These technological paradigm shifts require revised curricula that include data science. Providing high school students with an initial toolbox enables them to build additional skills throughout college and their careers. The Curriculum and Community Enterprise for Restoration Science STEM + C project has developed a curriculum that combines all of these elements.

Table 1. Curricula for Teachers and Students

\begin{tabular}{ll}
\hline Curricula Topics for Teachers & Curricula Topics for Students \\
\hline Data and Data Analysis Teacher Tool Kit & Field Questions about Oysters \\
Data about New York Harbor & Choose a question for data analysis \\
Helping Students choose data & Choose your data \\
New York Harbor Oysters Map & Make and test your predictions \\
Example of Harbor Oyster Dataset & Data Analysis Tracker (for Students) \\
New York Harbor Data Source Library & Feedback, reflection, and revision \\
Help using Google Sheets & Oyster ecology background reading \\
Statistics and Analysis (for Teachers) & Correlation and Causation \\
Different Ways to Visualize Data & Select variables to test for relationships \\
Project Outline and Assignment Tracker & Predict and test relationships between variables \\
\hline
\end{tabular}

Each of these topics is linked to resources that identify, explain and clarify the content described. For example, Harbor Oyster Data (figure 2) sets include the following:

1. Set Date - This is the date that the oyster larvae were put in a tank with oyster shells so that the larvae could settle (or set) on the shell permanently.

2. Distribution Data - This is the date the oysters were placed in the Oyster Research Station at the site.

3. Collection Date - This is the date the data collection took place - you can compare the growth of the oysters between the collection dates.

4. Shell Height - This is how we measure the size of the oyster, measuring from hinge to bill.

5. Total Live - This is the total number of live oysters on the given collection date.

6. Brood Stock - This is the code that indicates the place of origin for the oysters at the site.

Site - This is the location of the Oyster Restoration site in New York Harbor (Use this map).

7. Organization - This is the name of the citizen science group, school or individual that collected the data. 
Table 2. Oyster Research Station Data

\begin{tabular}{|c|c|c|c|c|c|c|c|}
\hline $\begin{array}{l}\text { Set } \\
\text { Date }\end{array}$ & $\begin{array}{l}\text { Distribution } \\
\text { Date }\end{array}$ & $\begin{array}{l}\text { Collection } \\
\text { Date }\end{array}$ & $\begin{array}{l}\text { Shell height } \\
(\mathrm{mm})\end{array}$ & $\begin{array}{l}\text { Total } \\
\text { live }\end{array}$ & $\begin{array}{l}\text { Brood } \\
\text { stock }\end{array}$ & Site & Organization \\
\hline $3 / 28 / 17$ & $7 / 13 / 18$ & $7 / 22 / 18$ & 40 & 46 & GK & $\begin{array}{l}\text { 2nd Street } \\
\text { Sponge Park }\end{array}$ & $\begin{array}{l}\text { Gowanus } \\
\text { Dredgers }\end{array}$ \\
\hline $3 / 28 / 17$ & $7 / 13 / 18$ & $7 / 22 / 18$ & 44 & 46 & GK & $\begin{array}{l}\text { 2nd Street } \\
\text { Sponge Park }\end{array}$ & $\begin{array}{l}\text { Gowanus } \\
\text { Dredgers }\end{array}$ \\
\hline $3 / 28 / 17$ & $7 / 13 / 18$ & $7 / 22 / 18$ & 35 & 46 & GK & $\begin{array}{l}\text { 2nd Street } \\
\text { Sponge Park }\end{array}$ & $\begin{array}{l}\text { Gowanus } \\
\text { Dredgers }\end{array}$ \\
\hline $3 / 28 / 17$ & $7 / 13 / 18$ & $7 / 22 / 18$ & 21 & 46 & GK & $\begin{array}{l}\text { 2nd Street } \\
\text { Sponge Park }\end{array}$ & $\begin{array}{l}\text { Gowanus } \\
\text { Dredgers }\end{array}$ \\
\hline $3 / 28 / 17$ & $7 / 13 / 18$ & $7 / 22 / 18$ & 19 & 46 & GK & $\begin{array}{l}\text { 2nd Street } \\
\text { Sponge Park }\end{array}$ & $\begin{array}{l}\text { Gowanus } \\
\text { Dredgers }\end{array}$ \\
\hline $3 / 28 / 17$ & $7 / 13 / 18$ & $7 / 22 / 18$ & 45 & 46 & GK & $\begin{array}{l}\text { 2nd Street } \\
\text { Sponge Park }\end{array}$ & $\begin{array}{l}\text { Gowanus } \\
\text { Dredgers }\end{array}$ \\
\hline $3 / 28 / 17$ & $7 / 13 / 18$ & $7 / 22 / 18$ & 34 & 46 & GK & $\begin{array}{l}\text { 2nd Street } \\
\text { Sponge Park }\end{array}$ & $\begin{array}{l}\text { Gowanus } \\
\text { Dredgers }\end{array}$ \\
\hline
\end{tabular}

\section{Results}

As reported in the evaluation of the project, participating in the BOP CCERS STEM + C Project does increase student knowledge about STEM careers and improves their perceptions of their scientific skills compared to those with less involvement in the project. Although many student activities were interrupted due to the COVID-19 pandemic, particularly around student participation at field sites, greater gains are expected as new student programs like the Near-Peer Career Panels, are introduced.

Students were highly engaged in the Oyster Research Station (ORS) monitoring and research activities. Fieldwork included the use of the research protocols to collect water quality data, take oyster measurements, identify other marine species in the ORS, and test each other's work for accuracy. Surveyed students responded most positively to the question, "How confident do you feel about collecting and analyzing data?" The survey instrument used was a Likert scale with 1.0 "least confident" and 5.0, "most confident". The response rating was 3.64 (standard deviation - 0.84).

Near-Peer Mentoring involved pairing older and younger students for oyster research mentoring to engage students in waterfront research activities and create student awareness and interest in pursuing careers in the marine sciences, the environment, and related STEM fields. Due to COVID-19, this was implemented on a smaller scale than originally intended. Students were able to explore maritime careers taught at the Harbor School, promoting student career interest. Career webinars were created with panels of maritime STEM professionals to compensate for the lack of in-person engagement with STEM careers.

The teachers in the project were asked about their reasons for motivating student engagement in the content and student interest in STEM. "To promote student understanding of their capacity to become active stewards of the environment" was chosen by eighty-three percent $(83 \%)$ of the teachers. In terms of the professional development that the teachers received, eighty-three percent (83\%) thought that the lessons and activities would increase student awareness of STEM careers.

Students were asked if they understood that their actions were those of a scientist and if they thought it possible to become a scientist based on their experiences in the BOP CCERS STEM + C Project. The survey instrument used was a Likert scale with 1.0 "least likely to see him/herself as a scientist", and 6.0, "most likely to see him/herself as a scientist". The response rating was 5.32 (standard deviation $=0.93$ ).

\section{Discussion}

Data Science offers one of the most promising long-term career fields of the last decade. The value of global databases cannot be understated. The mining of, the analysis, and the interpretation of data has improved developments in a variety of fields from economics to scientific research and many other fields. Data science incorporates mathematics, computer science and communications. The need for the next generation of students to interact with data is paramount. Much like biology, chemistry, and physics, high school students should start to build a strong foundation in data 
science early in their educational training to support progressive proficiency in data science later. (Columbus, 2017)

A 2019 report, by the National Association of Manufacturing and consulting firm Deloitte, predicted that while the U.S. will create 3.5 million STEM jobs by 2025, approximately 2 million jobs will go unfilled due to a lack of skilled workers. High school is the ideal setting for initial exposure to data science. Research has shown that early exposure to math and science courses in high school encourages students to pursue higher education in STEM and continue their studies even as the material becomes more challenging (Wang, 2013).

With particular regard to data science, there is a projected $16 \%$ growth of data scientist employment by the year 2028 (U.S. Bureau of Labor Statistics, 2021), faster than all other professions. The demand for educational trained and highly skilled data scientists is projected to steadily increase with the improvement of data mining techniques. Current high school students are digital natives and as such are comfortable with exploring datasets to answer multifaceted questions to explain natural and manmade phenomena.

The Curriculum and Community Enterprise for Restoration Science Projects focus on data science and computational thinking and provides researchers with additional information towards understanding the educational efforts needed to increase the diversity of the STEM workforce and the needed interventions for accomplishment. Specifically, educators should focus on scaffolding the development of students' computational thinking as it pertains to data analysis and interpretation, designing a model or a plan for data analysis that involves computational thinking and making the learning experience relevant, problem-based, and tied to a community-based conundrum that touches the lives of the students in the classroom and field. Students are more likely to value their science learning experiences when they see the content as personally relevant. We have an obligation to prepare all students, regardless of cultural background, ethnicity, or gender, to function in our modern science-based society (Chiappetta \& Koballa, 2010).

More than 6,000 NYC students in 100 schools, grades K-12, participate in the Curriculum and Community Enterprise for Restoration Science Projects through the STEM curriculum that focuses on New York City's waterways and native species, with a particular focus on oyster restoration. Most of these students are from high-poverty communities and are from underserved and underrepresented populations. Their exposure to the program and curricula that focus on local environmental issues is a significant step in changing the culture of STEM education in New York City schools. It also represents a viable pathway for underrepresented students to continue on the STEM pipeline from elementary to secondary and post-secondary education through career possibilities. STEM careers, especially in data science and computing are both abundant and well-compensated.

Each spring a symposium is held to showcase NY Harbor-themed projects that were initiated through the students' engagement with the BOP CCERS STEM + C Project. Students demonstrate awareness of the environment, a sense of ownership of the environment, knowledge about CSOs (combined sewer overflow) and how harmful they are, the importance of oysters and biodiversity, and an environmental call for action that was addressed in many of the projects. Students see themselves as stewards of the harbor, as community scientists, and by being involved, possibly leading to careers in the environment and industry.

In 2015, middle school \& high school students at West End Secondary School learned that recycled oyster shells are vital to restoring oyster reefs in NY Harbor and organizations like BOP need tons of it. The students drafted what is now New York State Bill S. 4741/A.258, sponsored by Assembly Member Linda Rosenthal. Over the past seven years, over 47 million oysters have been restored and over 200,000 pounds of oyster shells are collected from restaurants each year that would have otherwise been dumped in landfills.

The teacher and student curricula, developed through the BOP CCERS STEM + C Projects, focus on community awareness and environmental restoration through problem-based learning. Through the problem-based learning approach, students learn to bridge community-based knowledge and school-based knowledge, providing intellectual and meaningful learning through practical experience (Nguyen, Nguyen, \& Tran, 2020). Creating opportunities for students to not only develop content knowledge but to also have hands-on experiences, engage in STEM course content with peers, and identity as scientists seems particularly important (Griffin, 2018).

Lastly, including near-peer mentoring and career exploration to the original BOP CCERS model has provided the most underserved students added incentive to pursue STEM coursework and the tenacity to continue into STEM career options. As stated in a recent study, "near-peer mentors report benefits that include an increased sense of belonging and science identity, as well as improved self-efficacy. These factors are important for increasing the persistence of underrepresented minority students in STEM" (Trujillo \& Tanner, 2014). Lack of exposure to STEM professionals during $\mathrm{K}-12$ schooling can result in a false belief that individuals from their particular demographic 
generally do not go on to be scientists (Syed, Azmitia, \& Cooper, 2011). A recent study examining the factors influencing students' STEM career choices found that their limited knowledge of STEM careers hinders STEM career aspirations (Blotnicky, Franz-Odenaal, French \& Joy, 2018).

An inclusive and diverse workforce is essential to both the individual and society as a whole. With increased dependence on data to make informed decisions, college and career pathways in data science provide viable educational and economic opportunities for underserved and underrepresented populations of students in New York City. The Curriculum and Community Enterprise for Restoration Science is filling a long standing void for these students. Through the ecological restoration of New York Harbor, the data collecting experiences has not only restored the quality of the water and the abundance of aquatic species, it has also given the students the possibility of acquiring the STEM skills and content needed as encouragement to pursue data science as a feasible educational choice in post-secondary work and as an employment avenue that reduces inequality and offers financial stability.

\section{References}

Birney, L., \& McNamara, D. (2017). Authentic Community Based Learning in New York City: An Holistic Model using the Billion Oyster Project and Curriculum and Community Enterprise for Restoration Science. Journal of Education and Human Development, December, 6(4), 1-15. https://doi.org/10.15640/jehd.v6n4a1

Blotnicky, K. A., Franz-Odendaal, T., French, F., \& Joy, P. (2018). A study of the correlation between STEM career knowledge, mathematics self-efficacy, career interest, and career activities on the likelihood of pursuing a STEM career among middle school students. International Journal of STEM Education, 5(1). https://doi.org/10.1186/s40594-018-0118-3

Botella, C., Rueda, S., Lopez-Inesta, E., \& Marzal, P. (2019). Gender Diversity in STEM Disciplines: A Multiple Factor Problem. Entropy, 21, 30. https://doi.org/10.3390/e21010030

Boyd, D., \& Crawford, K. (2021). Critical Questions for Big Data. Information, Communication and Society, 15(5), 662-679. https://doi.org/10.1080/1369118X.2012.678878

Chiappetta, E. L., \& Koballa, T. R. (2010). Science Instruction in the Middle and Secondary Schools. Boston, MA: Allyn \& Bacon.

Columbus, L. (2017). IBM Predicts Demand for Data Scientist Will Soar $28 \%$ by 2020. Forbes Magazine. Retrieved 13 May, 2017 from https://www.forbes.com/louiscolumbus

Foley, B. J., \& McPhee, C. (2006). Students' Attitudes towards Science in Classes Using Hands-on or Textbook Based Curriculum, American Educational Research Association. Retrieved from www.aera.net/

Gibbs, K. (2014). Diversity in STEM: What It Is and Why It Matters. Scientific American. Retrieved 10 September, 2014 from https://blogs.scientificamerican.com/voices/diversity-in-stem-what-it-is-and-why-it-matters/

Griffin, K. A. (2018). Addressing STEM Culture and Climate to Increase Diversity in STEM Disciplines. Higher Education Today, American Council on Education. Retrieved from https://www.higheredtoday.org/2018/04/23/addressing-stem-culture-climate-increase-diversity-stem-disciplines /

Hamrick, K. (2019). Women, minorities, and persons with disabilities in science and engineering. Special report NSF 19-304. Alexandria: National Science Foundation, National Center for Science and Engineering Statistics (NCSES) https://www.nsf.gov/statistics/wmpd

Hazari, Z., Sadler, P. M., \& Sonnert, G. (2013). The science identity of college students: exploring the intersection of gender, race, and ethnicity. Journal of College Science Teaching, 42(5), 82-91.

Kricorian, K., Seu, M., Lopez, D., Ureta, E., \& Equils, O. (2020). Factors Influencing Participation of underrepresented students in STEM fields: matched mentors and mindsets. International Journal of STEM Education, 7, 16. https://doi.org/10.1186/s40594-020-00219-2

NGSS Lead States (2013). Next Generation Science Standards: For States, By States. Washington, DC: The National Academies Press. https://doi.org/10.17226/18290

Nagrale, P. (2021). The 10 most interesting jobs in 2021. Sure Job: Education, Career \& Money. Retrieved April 20, 2021 from https://surejob.in/most-interesting-jobs.html

National Academy of Science (2010). Rising above the gathering storm, revisited: Rapidly approaching category 5. 
Washington, D.C.: The National Academies Press. https://doi.org/10.17226/12999

National Academies of Sciences, Engineering, and Medicine (2018). Envisioning the Data Science Discipline: The Undergraduate Perspective: Interim Report. Washington, DC: The National Academies Press. https://doi.org/10.17226/24886

National Research Council (2009). Learning science in informal environments: People, places, and pursuits. Washington, DC: The National Academies Press. https://doi.org/10.17226/12190

National Research Council (2012). A Framework for New K-12 Science Education: Practices, Crosscutting Concepts, and Core Ideas. Washington, D.C.: The National Academies Press. https://doi.org/10.17226/13165

Nguyen, T. P. L., Nguyen, T. H., \& Tran, T. K. (2020). STEM Education in Secondary Schools: Teachers' Perspective towards Sustainable Development. Sustainability 2020, 12(21), 8865. https://doi.org/10.3390/su12218865

Rattan, A., Savani, K., Chugh, D., \& Dweck, C. S. (2015). Leveraging mindsets to promote academic achievement: policy recommendations. Perspectives on Psychological Science, 10(6), 721-726. https://doi.org/10.1177/1745691615599383

Robnett, R. D., Nelson, P. A., Zurbriggen, E. L., Crosby, F. J., \& Chemers, M. M. (2018). Research mentoring and scientist identity: insights from undergraduates and their mentors. International Journal of STEM Education, 5 , 41. https://doi.org/10.1186/s40594-018-0139-y

Ritchie, H., \& Roser, M. (2018). $\mathrm{CO}_{2}$ and Greenhouse Gas Emissions. Retrieved from https://ourworldindata.org/co2-and-otherpgreenhouse-gas-emissions

Syed, M., Azmitia, M., \& Cooper, C. R. (2011). Identity and Academic Success among Underrepresented Ethnic Minorities: An Interdisciplinary Review and Integration, Journal of Social Issues, 67(3), 442-468. https://doi.org/10.1111/j.1540-4560.2011.01709.x

Trujillo, G., \& Tanner, K. D. (2014). Considering the role of affect in learning: Monitoring student's self-efficacy, sense of belonging, and science identity. CBE Life Science Education, 13(1), 6-15. https://doi.org/10.1187/cbe.13-12-0241

United Nations, General Assembly (2015). Sustainable Development Goals. Retrieved from https://sdgs.un.org/

UNESCO (2019). Women in Science. Fact Sheet, (55). Retrieved from http://uis.unesco.org/sites/default/files/documents/fs55-women-in-science-2019-en.pdf

U.S. Bureau of Labor Statistics (2021). Occupational Outlook Handbook-Computer and Research Information Scientists.

Retrieved

from https://www.bls.gov/ooh/computer-and-inforation-technology/computer-and-inforation-research-scientists.htm

U.S. Department of Education for Civil Rights (2014). Civil Rights Data Collection, Data Snapshot: College and Career Readiness. Issue Brief, (3). Retrieved from http://ocrdata.ed.gov

Wang, X. (2013). Why Students Chose STEM Majors: Motivation, High School Learning, and Postsecondary Context of Support. American Educational Research Journal, 50(5), 1081-1121. https://doi.org/10.3102/0002831213488622

Zaniewski, A. M., \& Reinholz, D. (2016). Increasing STEM success: a near-peer mentoring program in the physical sciences. International Journal of STEM Education, 3(14). https://doi.org/10.1186/s40594-016-0043-2

\section{Copyrights}

Copyright for this article is retained by the author(s), with first publication rights granted to the journal.

This is an open-access article distributed under the terms and conditions of the Creative Commons Attribution license (http://creativecommons.org/licenses/by/4.0/). 